Supporting Information for

\title{
Substituent Effects on the Reactions of Diarylgermylenes and Tetraaryldigermenes with Acetic Acid and Other Lewis Bases in Hydrocarbon Solvents
}

\author{
Lawrence A. Huck and William J. Leigh* \\ Department of Chemistry, McMaster University, Hamilton ON L8S 4M1, Canada
}

Figure S1. Concentration vs. time plots for (a) 1a-d, (b) 4a-d, and (c) 2,3-dimethyl-1,3- S3 butadiene $(\mathrm{DMB})$ from photolysis of 1a-d $(0.02 \mathrm{M})$ in cyclohexane- $d_{12}$ containing $0.2 \mathrm{M}$ MeOH. [a ( $\left.-\mathrm{H}), \mathbf{b}\left(\square-\mathrm{CH}_{3}\right), \mathbf{c}(\bullet-\mathrm{F}), \mathbf{d}\left(\mathbf{\square}-\mathrm{CF}_{3}\right)\right]$

Figure S2. Representative ${ }^{1} \mathrm{H}$ NMR spectra from photolysis of $\mathbf{1 d}$ in $\mathrm{C}_{6} \mathrm{D}_{12}$ containing $\mathrm{MeOH}(0.2 \mathrm{M})$ and $\mathrm{Si}_{2} \mathrm{Me}_{6}$ (as internal integration standard).

Figure S3. ${ }^{1} \mathrm{H}$ NMR spectrum of the crude reaction mixture from photolysis of $\mathbf{1 b}$ in S5 hexane containing HOAc $(0.4 \mathrm{M})$, after evaporation of the solvent and re-dissolution in $\mathrm{CDCl}_{3}$. The peaks marked with an asterisk, which are due to residual $\mathbf{1 b}$, illustrate the degree of conversion.

Figure S4. Transient UV/vis absorption spectra from laser flash photolysis of dry, deoxygenated solutions of $\mathbf{1 b}(0.003 \mathrm{M})$ at $25^{\circ} \mathrm{C}$, (a) in hexane $30-100 \mathrm{~ns}(\mathrm{O})$ and 3.49-3.52 $\mu$ s (•) after the laser pulse and (b) in hexane containing 15 mM THF 198-224 ns (०) and 3.43-3.48 $\mu \mathrm{s}(\bullet)$ after the laser pulse. The insets show transient absorption profiles recorded at 350, 440 and $500 \mathrm{~nm}$.

Figure S5. Transient UV/vis absorption spectra from laser flash photolysis of dry, deoxygenated solutions of $1 \mathrm{c}(0.003 \mathrm{M})$ at $25^{\circ} \mathrm{C}$, (a) in hexane $35-100 \mathrm{~ns}(\mathrm{O})$ and 3.56-3.58 $\mu \mathrm{s}(\bullet)$ after the laser pulse and (b) in hexane containing $7.3 \mathrm{mM}$ THF 326-352 ns (०) and 3.27-3.30 $\mu \mathrm{s}(\bullet)$ after the laser pulse. The insets show transient absorption profiles recorded at 345,440 and $500 \mathrm{~nm}$. 
Figure S6. Growth/decay profiles recorded at $440 \mathrm{~nm}$ and $500 \mathrm{~nm}$ by laser flash photolysis of optically matched (at $248 \mathrm{~nm}$ ) solutions of 1a-d (ca. $0.003 \mathrm{M}$ ) in dry, deoxygenated hexanes at $25{ }^{\circ} \mathrm{C}$. The traces shown in red are the corrected $500 \mathrm{~nm}$ decays, obtained by scaled subtraction of the $440 \mathrm{~nm}$ trace from the $500 \mathrm{~nm}$ one; the solid lines are the best fits of the data to second order decay kinetics.

Figure S7. Raw growth decay/profiles recorded at (a) $440 \mathrm{~nm}$ and (b) $500 \mathrm{~nm}$ by laser flash photolysis of a ca. $0.003 \mathrm{M}$ solution of $\mathbf{1 b}$ in hexane containing various concentrations of $\mathrm{AcOH}$ between 0 and $3 \mathrm{mM}$.

Figure S8. (a) Plots of $k_{\text {decay }}$ and $\Delta \mathrm{A}_{0} / \Delta \mathrm{A}_{\text {res }}$ for quenching of $\mathrm{GePh}_{2}$ (2a) by THF in hexane solution at $60{ }^{\circ} \mathrm{C}$. (b) Corrected $500 \mathrm{~nm}$ transient decay trace for $\mathrm{GePh}_{2}$ in hexane containing $2.0 \mathrm{mM} \mathrm{THF}$ at $60^{\circ} \mathrm{C}$, illustrating the procedure used for extraction of $k_{\text {decay }}$ and $\Delta \mathrm{A}_{\text {res }}$ values. The solid red line is the fit of the data to two first order exponential decays, from which $k_{\text {decay }}$ was obtained, while the solid black line is the value of $\Delta \mathrm{A}_{\text {res }}$, estimated as the break point in the bimodal decay. The $\Delta \mathrm{A}_{0}$ value used for calculation of $\Delta \mathrm{A}_{0} / \Delta \mathrm{A}_{\text {res }}$ values at each concentration was taken from the corrected $500 \mathrm{~nm}$ decay in the absence of added THF. 
Figure S1. Concentration vs. time plots for (a) 1a-d, (b) 4a-d, and (c) 2,3-dimethyl-1,3butadiene $(\mathrm{DMB})$ from photolysis of $1 \mathrm{a}-\mathbf{d}(0.02 \mathrm{M})$ in cyclohexane- $d_{12}$ containing $0.2 \mathrm{M} \mathrm{MeOH}$ [a $\left.(\mathrm{O}-\mathrm{H}), \mathbf{b}\left(\square-\mathrm{CH}_{3}\right), \mathbf{c}(\bullet-\mathrm{F}), \mathbf{d}\left(\mathbf{a}-\mathrm{CF}_{3}\right)\right]$. The integrals due to the methoxy protons in $4 \mathbf{a}-$ d were used to estimate the concentrations of these products at the various photolysis times monitored.
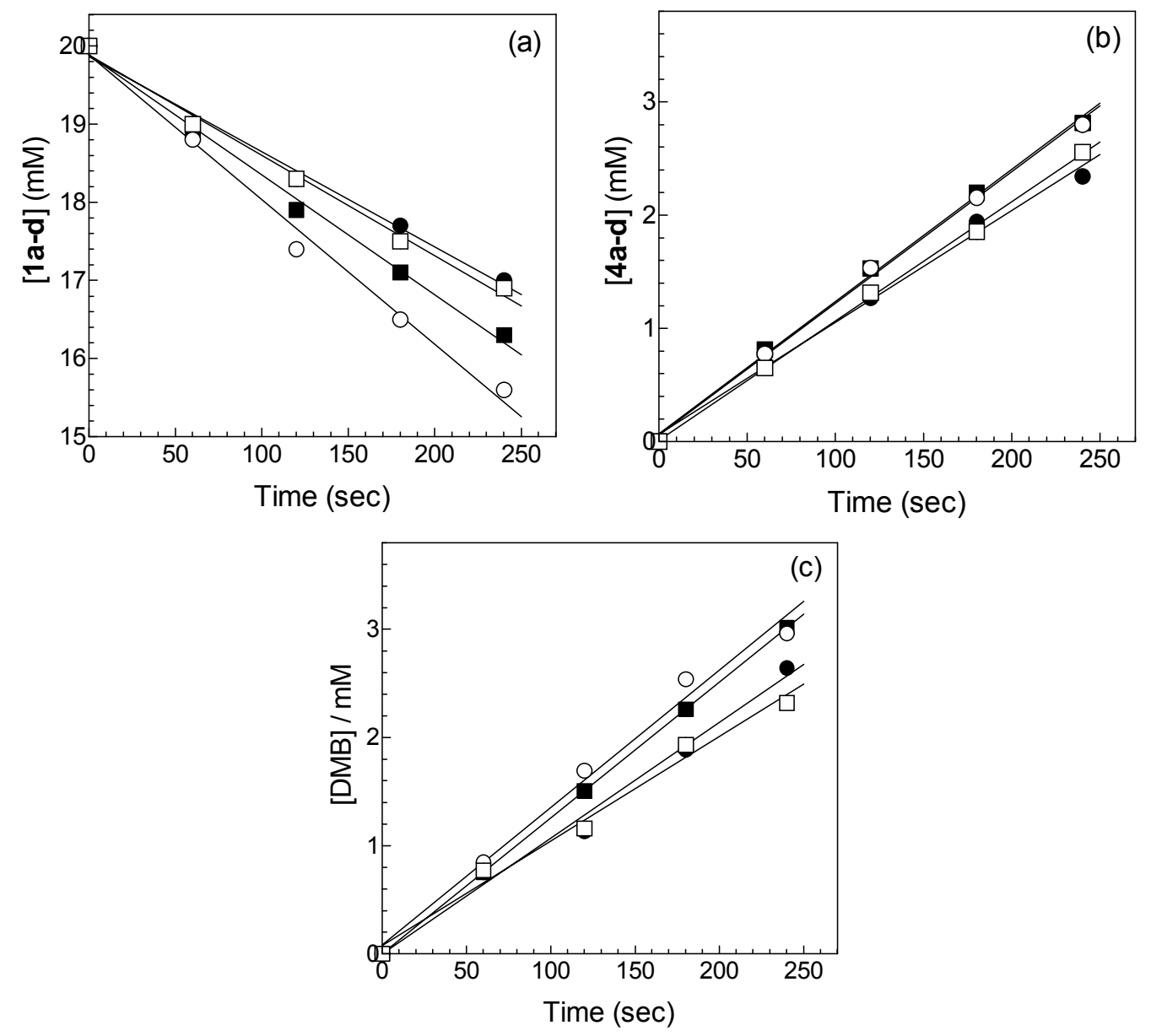

The slopes of the plots of Fig. S1b are listed below, with errors given as one standard deviation from the least squares analyses. Quantum yields for formation of $\mathbf{4 b}$-d were then calculated from the slopes relative to that for formation of $4 \mathbf{a}$ from 1a and the reported quantum yield for the latter reaction $(\Phi=0.55 \pm 0.07)$.
4a $(\mathrm{O}-\mathrm{H})$
$0.01163 \pm 0.00034 \mathrm{mM} \mathrm{s}^{-1}$
$\Phi=0.55 \pm 0.07$
4b $\left(\square-\mathrm{CH}_{3}\right)$
$0.01053 \pm 0.00021 \mathrm{mM} \mathrm{s}^{-1}$
$\Phi=0.50 \pm 0.09$
4c $(\bullet-F)$
$0.00988 \pm 0.00048 \mathrm{mM} \mathrm{s}^{-1}$
$\Phi=0.47 \pm 0.10$
4d $\left(\mathbf{a}-\mathrm{CF}_{3}\right)$
$0.01168 \pm 0.00037 \mathrm{mM} \mathrm{s}^{-1}$
$\Phi=0.55 \pm 0.10$ 
Figure S2. Representative ${ }^{1} \mathrm{H}$ NMR spectra from photolysis of $\mathbf{1 d}$ in $\mathrm{C}_{6} \mathrm{D}_{12}$ containing $\mathrm{MeOH}(0.2 \mathrm{M})$ and $\mathrm{Si}_{2} \mathrm{Me}_{6}$ (as internal integration standard).
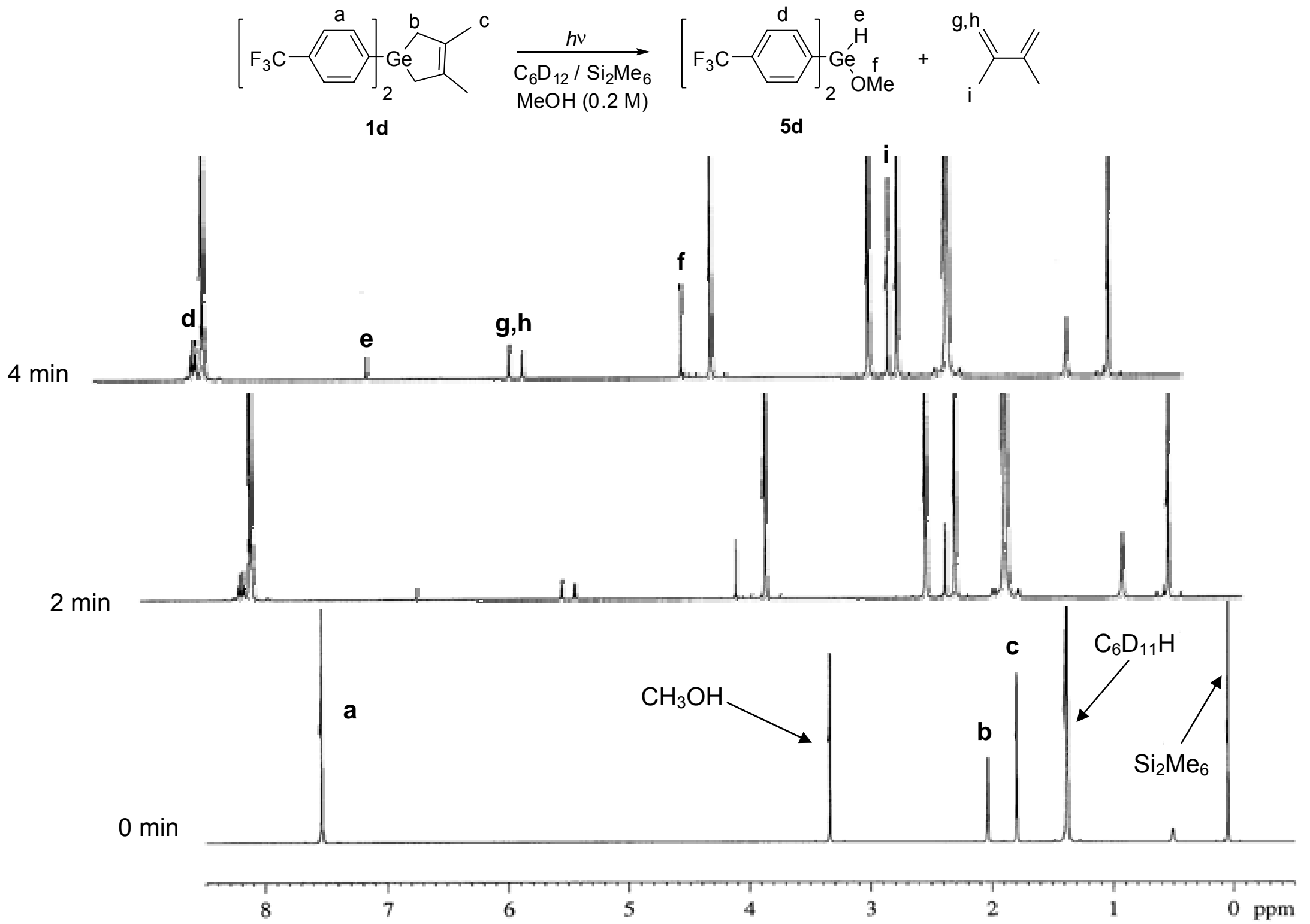
Figure S3. ${ }^{1} \mathrm{H}$ NMR spectrum of the crude reaction mixture from photolysis of $\mathbf{1 b}$ in hexane containing HOAc (0.4 M), after evaporation of the solvent and re-dissolution in $\mathrm{CDCl}_{3}$. The peaks marked with an asterisk, which are due to residual $\mathbf{1 b}$, illustrate the degree of conversion.

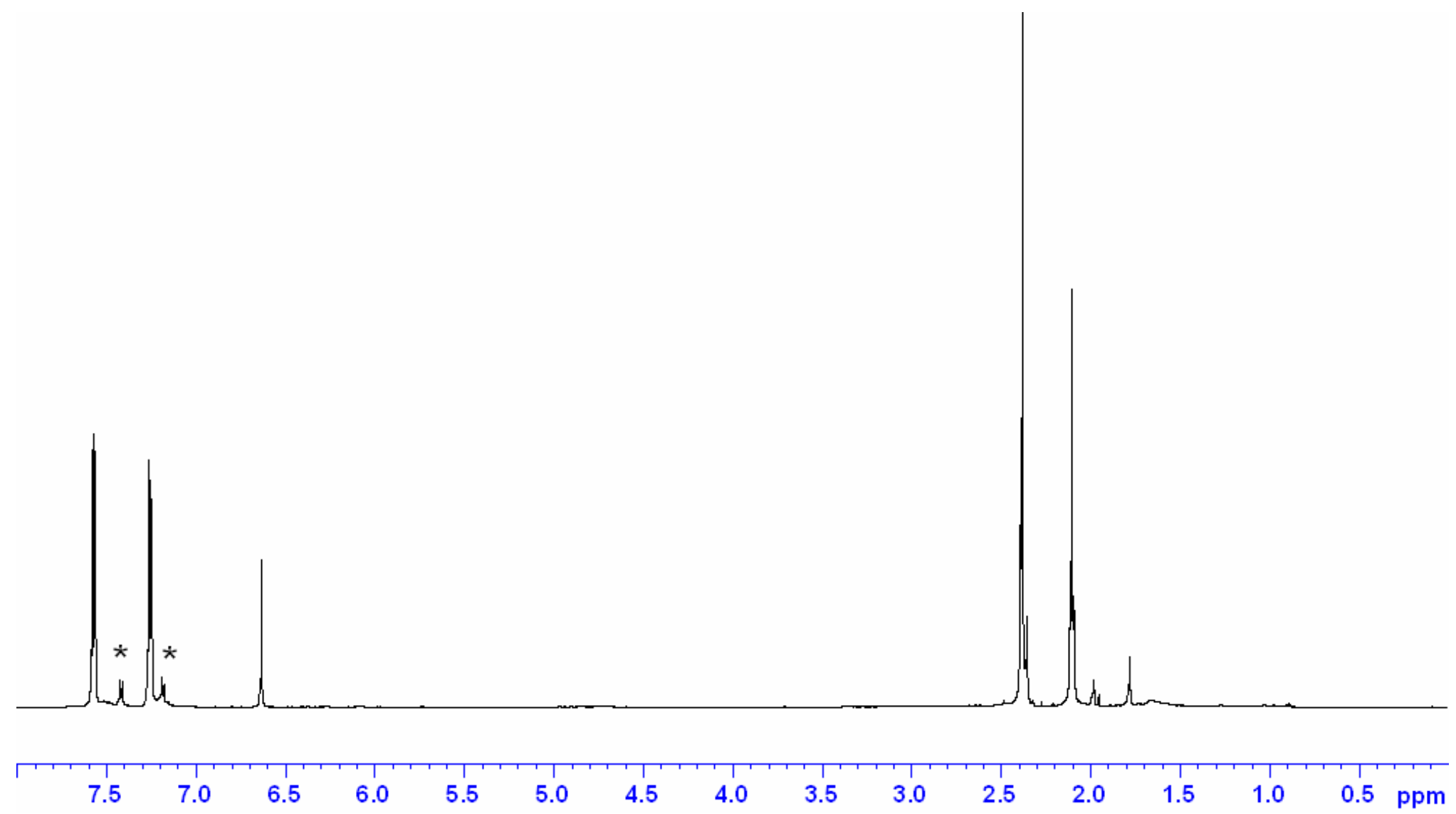


Figure S4. Transient UV/vis absorption spectra from laser flash photolysis of dry, deoxygenated solutions of $\mathbf{1 b}(0.003 \mathrm{M})$ at $25^{\circ} \mathrm{C}$, (a) in hexane 30-100 ns (०) and 3.49-3.52 $\mu \mathrm{s}(\bullet)$ after the laser pulse and (b) in hexane containing $15 \mathrm{mM}$ THF 198-224 ns (०) and 3.43-3.48 $\mu \mathrm{s}(\bullet)$ after the laser pulse. The insets show transient absorption profiles recorded at 350, 440 and $500 \mathrm{~nm}$.
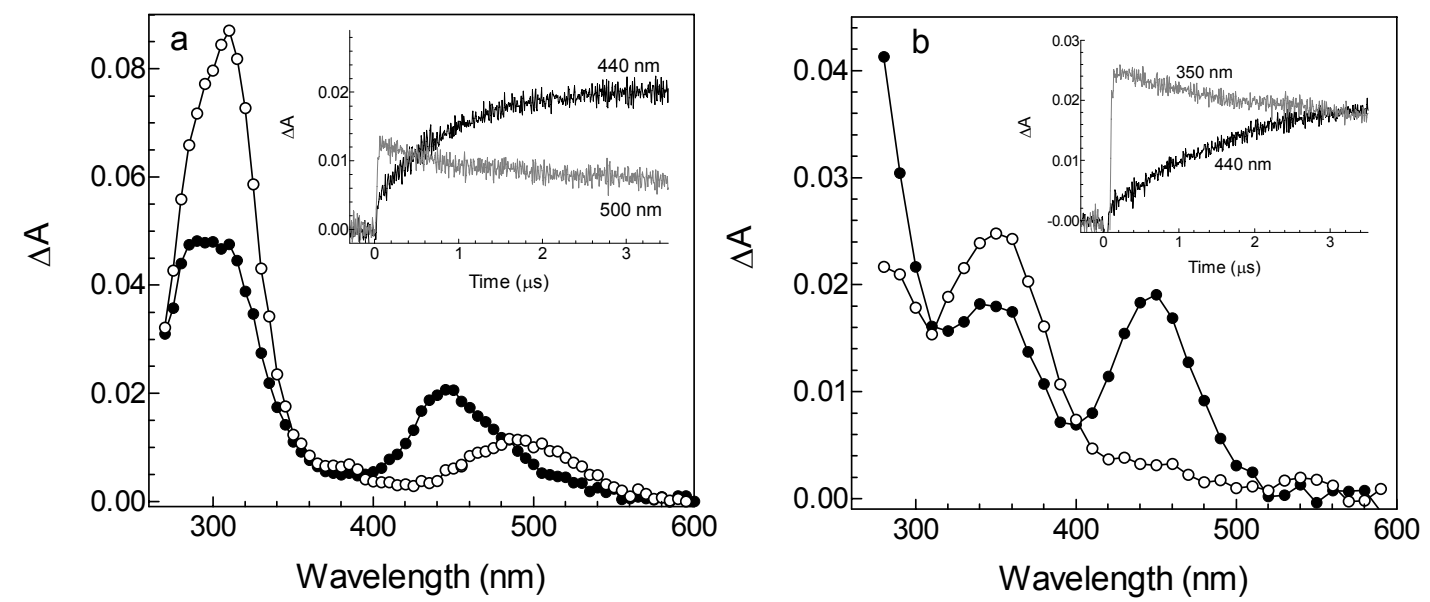

Figure S5. Transient UV/vis absorption spectra from laser flash photolysis of dry, deoxygenated solutions of 1c $(0.003 \mathrm{M})$ at $25^{\circ} \mathrm{C}$, (a) in hexane 35-100 ns (०) and 3.56-3.58 $\mu \mathrm{s}(\bullet)$ after the laser pulse and (b) in hexane containing 7.3 mM THF 326-352 ns (०) and 3.27-3.30 $\mu$ s (•) after the laser pulse. The insets show transient absorption profiles recorded at 345, 440 and $500 \mathrm{~nm}$.
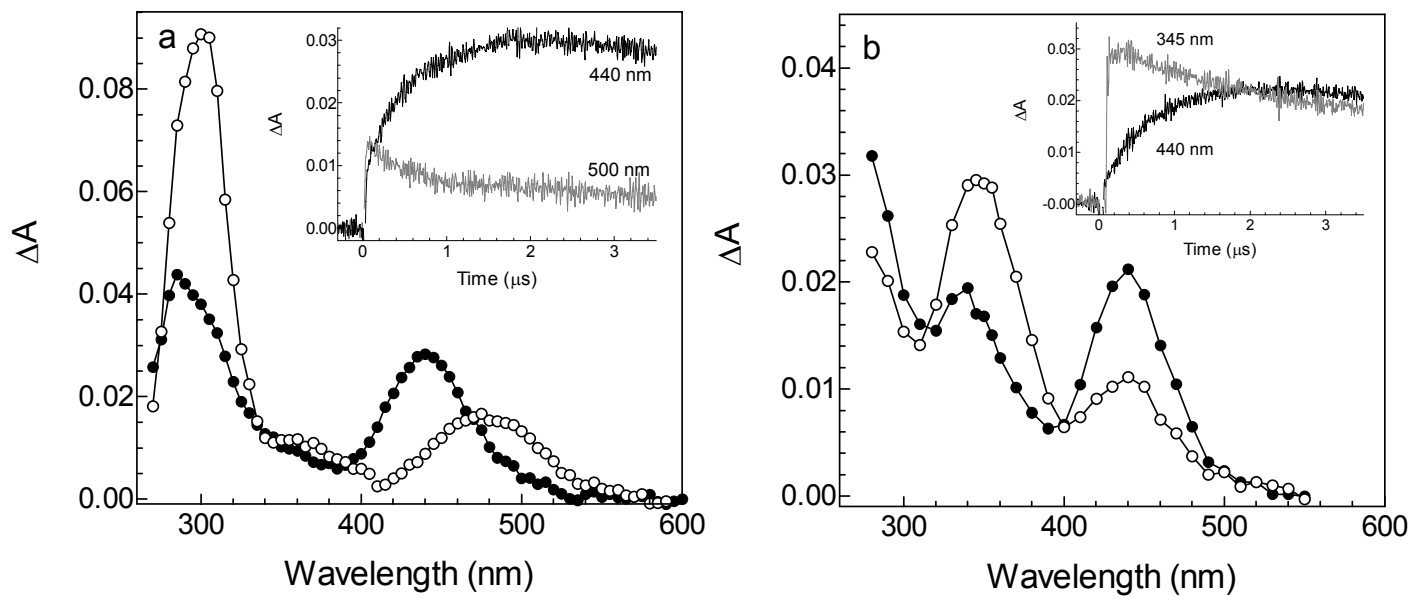
Figure S6. Growth/decay profiles recorded at $440 \mathrm{~nm}$ and $500 \mathrm{~nm}$ by laser flash photolysis of optically matched (at $248 \mathrm{~nm}$ ) solutions of 1a-d (ca. $0.003 \mathrm{M}$ ) in dry, deoxygenated hexanes at $25{ }^{\circ} \mathrm{C}$. The traces shown in red are the corrected $500 \mathrm{~nm}$ decays, obtained by scaled subtraction of the $440 \mathrm{~nm}$ trace from the $500 \mathrm{~nm}$ one; the solid lines are the best fits of the data to second order decay kinetics.
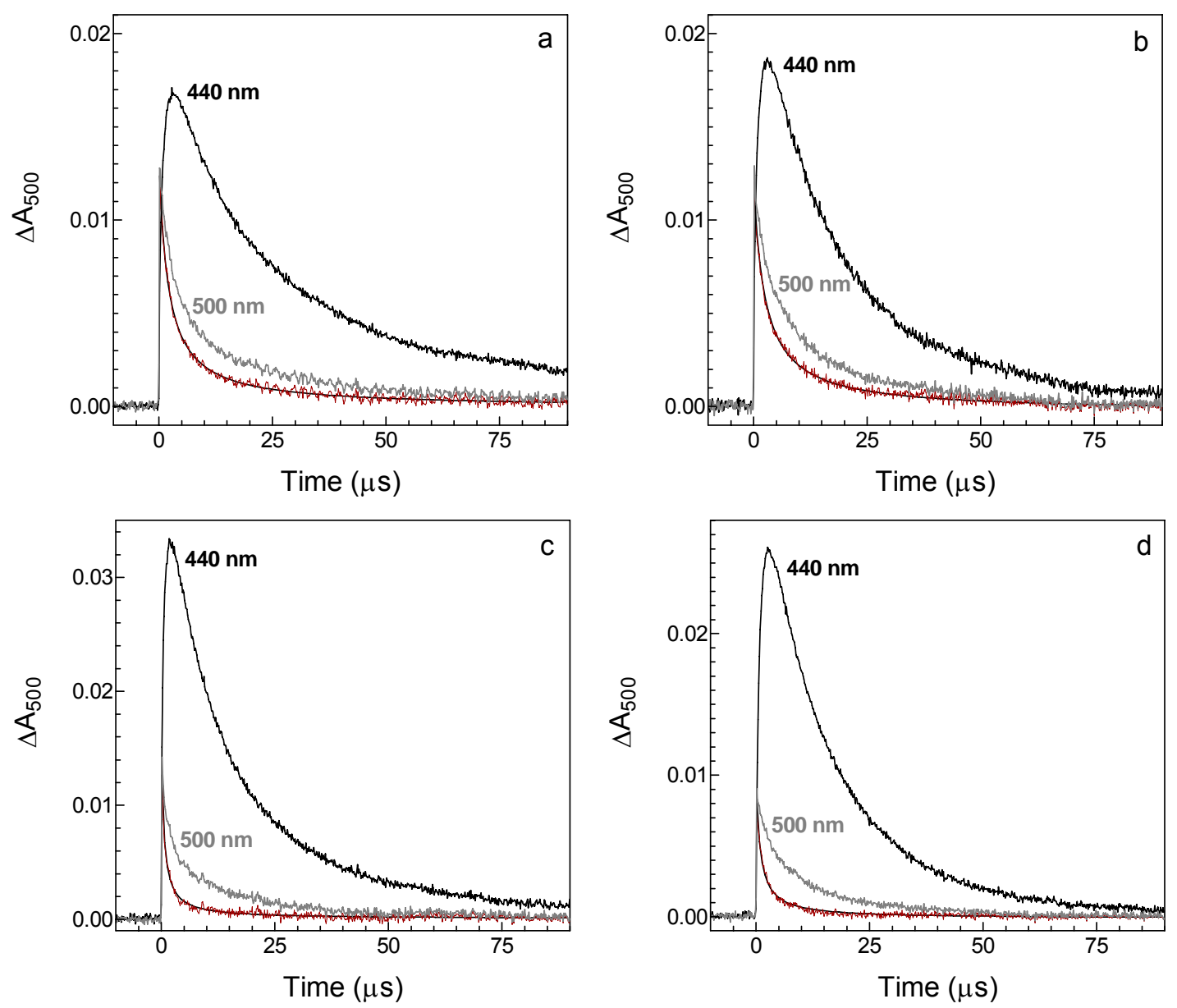
Figure S7. Raw growth decay/profiles recorded at (a) $440 \mathrm{~nm}$ and (b) $500 \mathrm{~nm}$ by laser flash photolysis of a ca. $0.003 \mathrm{M}$ solution of $\mathbf{1 b}$ in hexane containing various concentrations of $\mathrm{AcOH}$ between 0 and $3 \mathrm{mM}$.
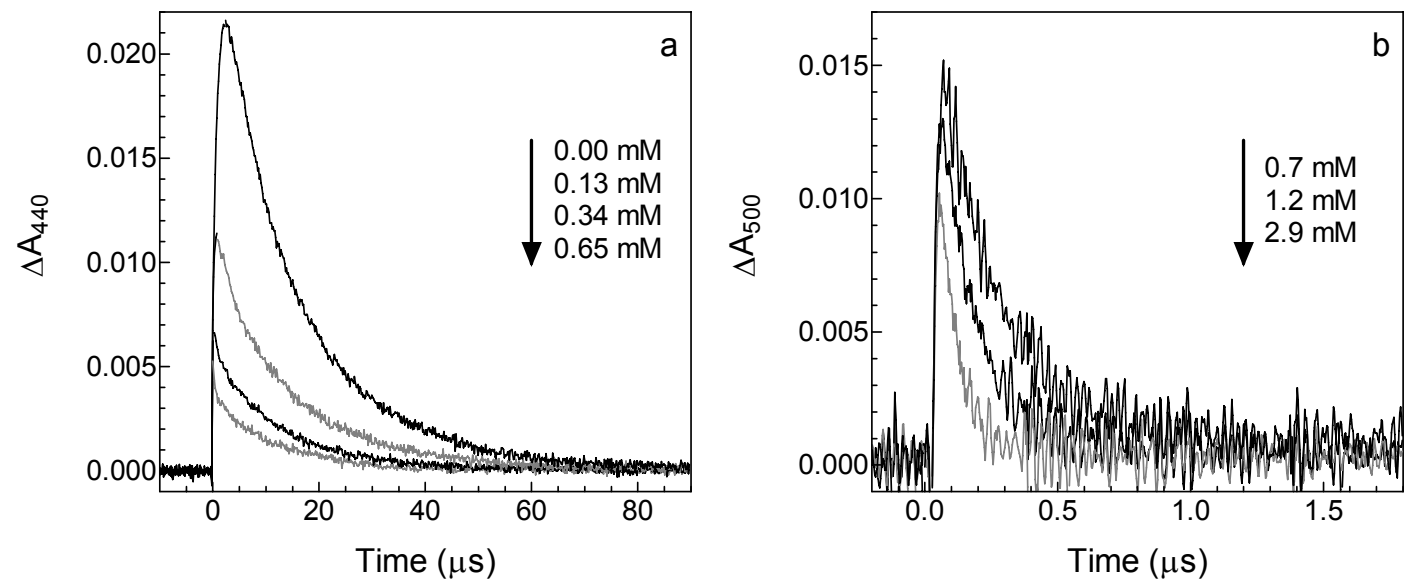

Figure S8. (a) Plots of $k_{\text {decay }}$ and $\Delta \mathrm{A}_{0} / \Delta \mathrm{A}_{\text {res }}$ for quenching of $\mathrm{GePh}_{2}$ (2a) by THF in hexane solution at $60{ }^{\circ} \mathrm{C}$. (b) Corrected $500 \mathrm{~nm}$ transient decay trace for $\mathrm{GePh}_{2}$ in hexane containing 2.0 $\mathrm{mM}$ THF at $60^{\circ} \mathrm{C}$, illustrating the procedure used for extraction of $k_{\text {decay }}$ and $\Delta \mathrm{A}_{\text {res }}$ values. The solid red line is the fit of the data to two first order exponential decays, from which $k_{\text {decay }}$ was obtained, while the solid black line is the value of $\Delta \mathrm{A}_{\text {res }}$, estimated as the break point in the bimodal decay. The $\Delta \mathrm{A}_{0}$ value used for calculation of $\Delta \mathrm{A}_{0} / \Delta \mathrm{A}_{\text {res }}$ values at each concentration was taken from the corrected $500 \mathrm{~nm}$ decay in the absence of added THF.
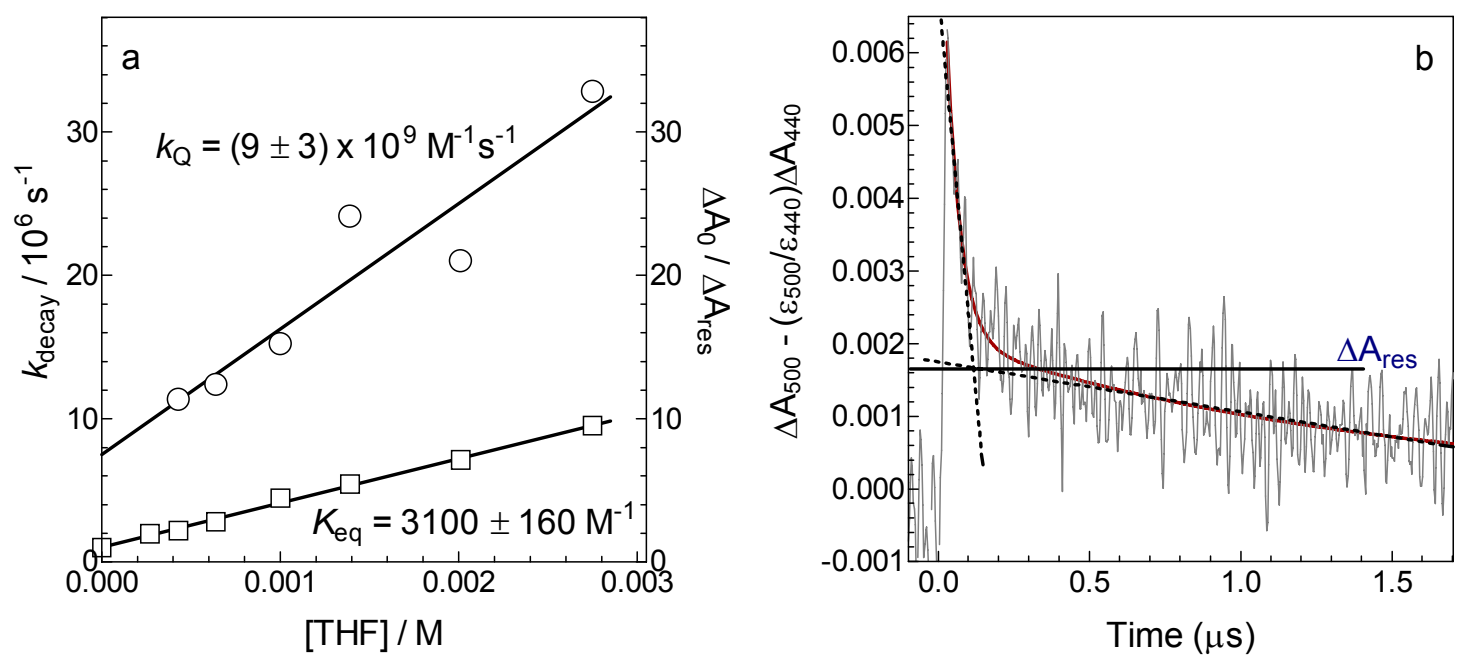


\section{Synthesis and Characterization of Compounds}

NMR spectra were recorded on Bruker AV200, DRX500, or AV600 spectrometers using the solvent $\left(\mathrm{CDCl}_{3}\right.$ unless otherwise noted) peak as a reference. Mass spectra were recorded on a Micromass TofSpec 2E mass spectrometer using electron impact (70 eV) or chemical ionization $\left(\mathrm{NH}_{3}\right.$ reagent gas, positive ion mode). Infrared spectra were recorded as thin-films on sodium chloride plates using a Bio-Rad FTS-40 FTIR spectrometer. Melting points were recorded using a Mettler FP82 hot stage mounted on a polarizing microscope and are uncorrected. Combustion analyses were performed by Guelph Chemical Laboratories Ltd., Guelph ON. Column chromatography was carried out using acid washed 230-400 mesh silica gel (Silicycle).

All synthetic preparations were carried out in conventional glassware under an atmosphere of dry nitrogen. 1,1-Dichloro-3,4-dimethylgermacyclopent-3-ene, ${ }^{1} 3,4$-dimethyl-1,1diphenylgermacyclopent-3-ene (1a), ${ }^{1}$ and hexamesitylcyclotrigermane $(\mathbf{4})^{2}$ were prepared as previously described.

The 1,1-diaryl-3,4-dimethylgermacyclopent-3-enes 1b-d were prepared by an analogous method to the preparation of 1a, and purified by column chromatography (silica gel, hexanes) and multiple recrystallizations from hexanes. They were identified on the basis of the following spectroscopic data ( $\mathrm{m} / \mathrm{z}$ values marked with * indicate ions containing $\left.{ }^{74} \mathrm{Ge}\right)$ :

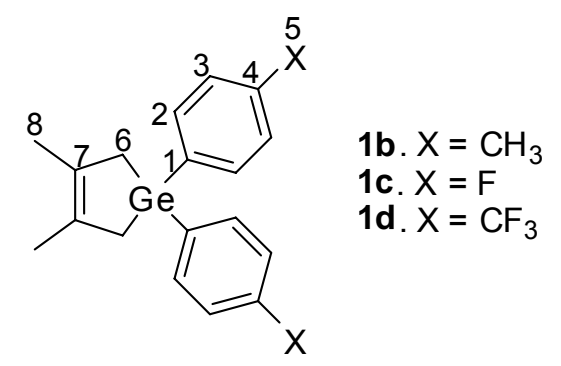

3,4-Dimethyl-1,1-di-(4-methylphenyl)-1-germacyclopent-3-ene (1b; mp $\left.81.4-83.7{ }^{\circ} \mathrm{C}\right) .{ }^{1} \mathrm{H} \mathrm{NMR}$, $\delta=1.78\left(\mathrm{~s}, 6 \mathrm{H}, \mathrm{C}^{8} \mathrm{H}_{3}\right), 1.98\left(\mathrm{~s}, 4 \mathrm{H}, \mathrm{C}^{6} \mathrm{H}_{2}\right), 2.36\left(\mathrm{~s}, 6 \mathrm{H}, \mathrm{C}^{5} \mathrm{H}_{3}\right), 7.19\left(\mathrm{~d}, 4 \mathrm{H}, J=7.8 \mathrm{~Hz}, \mathrm{C}^{3} \mathrm{H}\right), 7.42$ 
(d, 4H, $\left.J=7.8 \mathrm{~Hz}, \mathrm{C}^{2} H\right) ;{ }^{13} \mathrm{C}$ NMR, $\delta=19.55$ (C8), 21.56 (C5), 25.80 (C6), 129.11 (C2), 130.91

(C7), 134.32 (C3), $134.91(\mathrm{C} 1), 138.69$ (C4); IR, v (cm $\left.{ }^{-1}\right)=2914$ (m,br), $1911(\mathrm{w}), 1497$ (m), 1440 (m,br), 1264 (m), 1171 (m), 1157 (m), 1087 (m), 799 (s), 742 (m), 667 (m); MS, m/z (I) = $338.1 *(38), 256.0 *(100), 181.1$ (94), 164.9* (46), 139.0* (15); HRMS, calc for $\mathrm{C}_{20} \mathrm{H}_{24} \mathrm{Ge}$ : 338.1090, found: 338.1078; Anal., calc. for $\mathrm{C}_{20} \mathrm{H}_{24} \mathrm{Ge}$, C 71.28, H 7.18; found, C 70.91, H 6.99. 1,1-Di-(4-fluorophenyl)-3,4-dimethyl-1-germacyclopent-3-ene (1c; mp 83.1-84.8 $\left.{ }^{\circ} \mathrm{C}\right) .{ }^{1} \mathrm{H} \mathrm{NMR}$, $\delta=1.80\left(\mathrm{~s}, 6 \mathrm{H}, \mathrm{C}^{8} \mathrm{H}_{3}\right), 2.00\left(\mathrm{~s}, 4 \mathrm{H}, \mathrm{C}^{6} \mathrm{H}_{2}\right), 7.07\left(\mathrm{dd}, 2 \mathrm{H}, J=9,9 \mathrm{~Hz}, \mathrm{C}^{3} \mathrm{H}\right), 7.46(\mathrm{dd}, 2 \mathrm{H}, J=9,6$ $\left.\mathrm{Hz}, \mathrm{C}^{2} H\right) ;{ }^{13} \mathrm{C}$ NMR, $\delta=19.51(\mathrm{C} 8), 25.82(\mathrm{C} 6), 115.55\left(\mathrm{~d},{ }^{2} J_{\mathrm{C}-\mathrm{F}}=20 \mathrm{~Hz}, \mathrm{C} 3\right), 130.87(\mathrm{C} 7)$ $133.40(\mathrm{C} 1), 136.00\left(\mathrm{~d},{ }^{3} J_{\mathrm{C}-\mathrm{F}}=7 \mathrm{~Hz}, \mathrm{C} 2\right), 163.81\left(\mathrm{~d},{ }^{1} J_{\mathrm{C}-\mathrm{F}}=248 \mathrm{~Hz}, \mathrm{C} 4\right) ; \mathrm{IR}, \mathrm{v}\left(\mathrm{cm}^{-1}\right)=2911$ (m,br), 1893 (w), 1587 (s), 1496 (m), 1230 (m), 1162 (m), $1086(\mathrm{~m}), 821(\mathrm{~m}), 743(\mathrm{~m}), 670(\mathrm{w})$; MS, $m / z(I)=346.1 *(50), 262.0 *(58), 169.0 *(100), 152.1(88), 92.9 *(70)$; HRMS, Calc. for $\mathrm{C}_{18} \mathrm{H}_{18} \mathrm{~F}_{2} \mathrm{Ge}, .346 .0588$; found, 346.0564; Anal. calc. for $\mathrm{C}_{18} \mathrm{H}_{18} \mathrm{~F}_{2} \mathrm{Ge}, \mathrm{C}$ 62.68, H 5.26; found, $\mathrm{C}$ 63.07, H 5.56.

3,4-Dimethyl-1,1-bis-(4-trifluoromethylphenyl)-1-germacyclopent-3-ene (1d, mp 59.2 - 60.0 $\left.{ }^{\circ} \mathrm{C}\right) ;{ }^{1} \mathrm{H}$ NMR, $\delta=1.80\left(\mathrm{~s}, 6 \mathrm{H}, \mathrm{C}^{8} \mathrm{H}_{3}\right), 2.06\left(\mathrm{~s}, 4 \mathrm{H}, \mathrm{C}^{6} \mathrm{H}_{2}\right), 7.62(\mathrm{~s}, 8 \mathrm{H}$, all $\mathrm{ArH}) ;{ }^{13} \mathrm{C} \mathrm{NMR}, \delta=$ $19.46(\mathrm{C} 8), 25.44(\mathrm{C} 6), 124.28\left(\mathrm{q},{ }^{1} J_{\mathrm{C}-\mathrm{F}}=272 \mathrm{~Hz}, \mathrm{C} 5\right), 124.96(\mathrm{C} 3), 130.86(\mathrm{C} 7), 131.38\left(\mathrm{q},{ }^{2} J_{\mathrm{C}-}\right.$ $\mathrm{F}=32 \mathrm{~Hz}, \mathrm{C} 4), 134.60(\mathrm{C} 2), 142.66(\mathrm{C} 1) ; \mathrm{IR}, \mathrm{v}\left(\mathrm{cm}^{-1}\right)=2915(\mathrm{~m}, \mathrm{br}), 1925(\mathrm{w}), 1607(\mathrm{~m}), 1394$ (m), $1325(\mathrm{~s}), 1167(\mathrm{~s}), 1129(\mathrm{~s}), 1058(\mathrm{~s}), 1019(\mathrm{~m}), 826(\mathrm{~m}), 690(\mathrm{~m}) ; \mathrm{MS}: \mathrm{m} / \mathrm{z}(\mathrm{I})=446.1^{*}$ (19), 271.1 (69), 252.1 (77), 219.0 (46), 126.0 (26); HRMS, Calc. for $\mathrm{C}_{20} \mathrm{H}_{18} \mathrm{~F}_{6} \mathrm{Ge}, 446.0524$; found 446.0501; Anal. calc. for $\mathrm{C}_{20} \mathrm{H}_{18} \mathrm{~F}_{6} \mathrm{Ge}, \mathrm{C} 53.99$, H 4.08; found, C 54.06, H 4.02.

Steady state photolysis experiments with 1a-d were carried out in quartz tubes (7 x 90 mm) or quartz NMR tubes on $0.5-1.0 \mathrm{~mL}$ aliquots of the appropriate solutions of the compounds $(0.02$ $-0.035 \mathrm{M}$ ) in dry hexanes or $\mathrm{C}_{6} \mathrm{D}_{12}$, and employed a Rayonet ${ }^{\circledR}$ photochemical reactor (Southern New England Ultraviolet Co.) equipped with a merry-go-round apparatus and two RPR-2537 
lamps $(254 \mathrm{~nm})$. The tubes were sealed with rubber septa and deoxygenated with a stream of dry argon for ca. 20 minutes, and then the appropriate amount of $\mathrm{MeOH}$ or $\mathrm{HOAc}$ was added via syringe.

Solutions of 1a-d in $\mathrm{C}_{6} \mathrm{D}_{12}$ containing $\mathrm{MeOH}(0.2 \mathrm{M})$ and a trace of $\mathrm{Si}_{2} \mathrm{Me}_{6}$ as internal standard were irradiated in parallel, monitoring the solutions by ${ }^{1} \mathrm{H}$ NMR spectroscopy in 1 minute time intervals to $\sim 20 \%$ conversion ( $4 \mathrm{~min}$ ). DMB and methoxygermanes $5 \mathbf{b}$-d were the only products detectable from $\mathbf{1 b}-\mathbf{d}$ in $>5 \%$ yield relative to consumed starting material in all cases. Identification of $\mathbf{5 b}$-d was made on the basis of comparisons of their ${ }^{1} \mathrm{H}$ NMR spectra to that of 5a. ${ }^{1}$ Attempted GC/MS analysis of the product mixtures afforded complex mixtures of germanium-containing compounds in addition to unreacted $\mathbf{1}$, but high resolution mass spectra of the photolyzed solutions without prior GC separation showed ions corresponding to the $\mathrm{M}^{+}$or $(\mathrm{M}-1)^{+}$ions of the three products. Quantum yields for formation of $\mathbf{5 b} \mathbf{b}-\mathbf{d}$ were determined from the slopes of concentration vs. time plots constructed from the NMR data (see Supporting Information), relative to that for formation of $5 \mathbf{a}$ from $1 \mathbf{a}(\Phi=0.55 \pm 0.07) .{ }^{1}$ The ${ }^{1} \mathrm{H}$ NMR and HRMS data for $\mathbf{5 b}-\mathbf{d}$ are as follows.

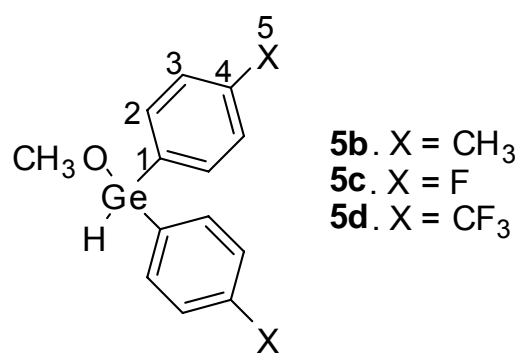

5b: ${ }^{1} \mathrm{H}$ NMR $\left(\mathrm{C}_{6} \mathrm{D}_{12}\right), \delta=2.30\left(\mathrm{~s}, 6 \mathrm{H}, \mathrm{C}^{5} \mathrm{H}_{3}\right), 3.50\left(\mathrm{~s}, 3 \mathrm{H}, \mathrm{OCH}_{3}\right), 6.05(\mathrm{~s}, \mathrm{H}, \mathrm{GeH}), 7.10(\mathrm{~d}, 4 \mathrm{H}$, $\left.J=7.8 \mathrm{~Hz}, \mathrm{C}^{3} \mathrm{H}\right), 7.39\left(\mathrm{~d}, 4 \mathrm{H}, J=7.8 \mathrm{~Hz}, \mathrm{C}^{2} \mathrm{H}\right)$; HRMS, calc. for $\mathrm{C}_{15} \mathrm{H}_{18} \mathrm{GeO}\left(\mathrm{M}^{+}\right), 288.0570$; found, 288.0572. 5c: ${ }^{1} \mathrm{H}$ NMR $\left(\mathrm{C}_{6} \mathrm{D}_{12}\right), \delta=3.53\left(\mathrm{~s}, 3 \mathrm{H}, \mathrm{OCH}_{3}\right), 6.10(\mathrm{~s}, \mathrm{H}, \mathrm{GeH}), 7.00(\mathrm{~m}, 4 \mathrm{H}$, $\left.\mathrm{C}^{3} \mathrm{H}\right), 7.44$ (m, 4H, $\mathrm{C}^{2} \mathrm{H}$ ). HRMS, calc. for $\mathrm{C}_{13} \mathrm{H}_{11} \mathrm{~F}_{2} \mathrm{GeO}(\mathrm{M}-\mathrm{H}), 294.9990$; found, 294.9986 .

5d: ${ }^{1} \mathrm{H}$ NMR $\left(\mathrm{C}_{6} \mathrm{D}_{12}\right), \delta=3.53\left(\mathrm{~s}, 3 \mathrm{H}, \mathrm{OCH}_{3}\right), 6.10(\mathrm{~s}, \mathrm{H}, \mathrm{GeH}), 7.00\left(\mathrm{~m}, 4 \mathrm{H}, \mathrm{C}^{3} \mathrm{H}\right), 7.44(\mathrm{~m}$, 
4H, $\left.\mathrm{C}^{2} \mathrm{H}\right)$; HRMS, calc. for $\mathrm{C}_{15} \mathrm{H}_{11} \mathrm{~F}_{6} \mathrm{GeO}(\mathrm{M}-\mathrm{H})$, 394.9926; found, 394.9929.

Solutions of 1b-d in hexanes containing HOAc $(0.4 \mathrm{M})$ were irradiated for two hours in parallel, and the solvent and excess HOAc were removed under high vacuum to afford yellow oils, the ${ }^{1} \mathrm{H}$ NMR spectra of which showed high conversion $(>80 \%)$ of the starting material to a single product major product $(>90 \%)$. These products were unstable towards silica gel chromatography or GC/MS and thus could not be isolated. Compounds 6b-d were thus identified on the basis of the following spectroscopic data, obtained on the crude reaction mixtures.

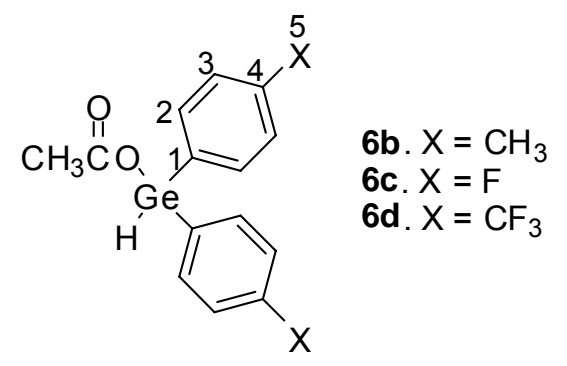

6b: ${ }^{1} \mathrm{H}$ NMR, $\delta=2.11(\mathrm{~s}, 3 \mathrm{H}, \mathrm{OAc}), 2.38\left(\mathrm{~s}, 6 \mathrm{H}, \mathrm{C}^{5} \mathrm{H}_{3}\right), 6.63(\mathrm{~s}, 1 \mathrm{H}, \mathrm{Ge} H), 7.25(\mathrm{~d}, 4 \mathrm{H}, J=7.9$ $\left.\mathrm{Hz}, \mathrm{C}^{3} \mathrm{H}\right), 7.57\left(\mathrm{~d}, 4 \mathrm{H}, J=7.5 \mathrm{~Hz}, \mathrm{C}^{2} \mathrm{H}\right) ;{ }^{13} \mathrm{C} \mathrm{NMR}, \delta=21.68(\mathrm{C} 5), 22.15\left(\mathrm{COCH}_{3}\right), 129.47$ (C2), $129.86(\mathrm{C} 1), 134.60(\mathrm{C} 3), 140.80(\mathrm{C} 4), 174.64(\mathrm{C}=\mathrm{O}) ; \mathrm{IR}, \mathrm{v}\left(\mathrm{cm}^{-1}\right)=2087 \mathrm{~cm}^{-1}(\mathrm{~m}), 2041$ (w), 1700 (s); HRMS, calc. for $\mathrm{C}_{16} \mathrm{H}_{17} \mathrm{GeO}_{2}(\mathrm{M}-\mathrm{H}), 316.0519$; found, 316.0512. 6c: ${ }^{1} \mathrm{H}$ NMR, $\delta$ $=2.12(\mathrm{~s}, 3 \mathrm{H}, \mathrm{OAc}), 6.65(\mathrm{~s}, \mathrm{H}, \mathrm{GeH}), 7.13-7.18\left(\mathrm{~m}, 4 \mathrm{H}, \mathrm{C}^{3} \mathrm{H}\right), 7.64-7.67\left(\mathrm{~m}, 4 \mathrm{H}, \mathrm{C}^{2} \mathrm{H}\right) ;{ }^{13} \mathrm{C}$ NMR, $\delta=22.00\left(\mathrm{COCH}_{3}\right), 116.13\left(\mathrm{~d},{ }^{2} J_{\mathrm{C}-\mathrm{F}}=20 \mathrm{~Hz}, \mathrm{C} 3\right), 128.49(\mathrm{C} 1), 136.70\left(\mathrm{~d},{ }^{3} J_{\mathrm{C}-\mathrm{F}}=7 \mathrm{~Hz}\right.$, C2), $164.70\left(\mathrm{~d},{ }^{1} J_{\mathrm{C}-\mathrm{F}}=251 \mathrm{~Hz}, \mathrm{C} 4\right), 174.66(\mathrm{C}=\mathrm{O}) ; \mathrm{IR}, \mathrm{v}\left(\mathrm{cm}^{-1}\right)=2049 \mathrm{~cm}^{-1}(\mathrm{~m}, \mathrm{br}), 1699(\mathrm{~s})$; HRMS, calc. for $\mathrm{C}_{14} \mathrm{H}_{11} \mathrm{~F}_{2} \mathrm{GeO}_{2}(\mathrm{M}-\mathrm{H}), 322.9939$; found, 322.9997. 6d: ${ }^{1} \mathrm{H} \mathrm{NMR}, \delta=2.16$ (s, $3 \mathrm{H}, \mathrm{OAc}), 6.75(\mathrm{~s}, \mathrm{H}, \mathrm{GeH}), 7.70\left(\mathrm{~d}, 4 \mathrm{H}, J=8.4 \mathrm{~Hz}, \mathrm{C}^{3} \mathrm{H}\right), 7.79\left(\mathrm{~d}, 4 \mathrm{H}, J=8.4 \mathrm{~Hz}, \mathrm{C}^{2} \mathrm{H}\right) ;{ }^{13} \mathrm{C}$ NMR, $\delta=21.81\left(\mathrm{COCH}_{3}\right), 123.95\left(\mathrm{q},{ }^{1} J_{\mathrm{C}-\mathrm{F}}=272 \mathrm{~Hz}, \mathrm{C} 5\right), 125.47(\mathrm{C} 2), 133.03\left(\mathrm{q},{ }^{2} J_{\mathrm{C}-\mathrm{F}}=32 \mathrm{~Hz}\right.$, C4), $135.00(\mathrm{C} 3), 137.85(\mathrm{C} 1), 174.74(\mathrm{C}=\mathrm{O}) ; \mathrm{IR}, \mathrm{v}\left(\mathrm{cm}^{-1}\right)=2101 \mathrm{~cm}^{-1}(\mathrm{~m}, \mathrm{br}), 1702(\mathrm{~s})$; HRMS, calc. for $\mathrm{C}_{16} \mathrm{H}_{11} \mathrm{~F}_{6} \mathrm{GeO}_{2}(\mathrm{M}-\mathrm{H}), 422.9875$; found, 422.9908. 
trace of $\mathrm{Si}_{2} \mathrm{Me}_{6}$ was carried out to $\sim 50 \%$ conversion, with periodic monitoring by NMR. The spectra showed the characteristic resonances of DMB and broad baseline absorption in the $\delta 6.5$ -8 chemical shift range.

Tetramesityldigermene (3e) was synthesized according to the procedure of Baines and coworkers. ${ }^{3}$ A solution of hexamesitylcyclotrigermane $\left(4 ; 18 \mathrm{mg}, 1.9 \times 10^{-5} \mathrm{~mol}\right)$ in dry toluene $(15 \mathrm{~mL})$ was placed in a $15 \times 150 \mathrm{~mm}$ quartz tube and sealed with a rubber septum.

Triethylsilane $\left(0.05 \mathrm{~mL}, 3.1 \times 10^{-4} \mathrm{~mol}\right)$ was then injected via syringe and the solution was deoxygenated with a fine stream of argon for $30 \mathrm{~min}$. It was then placed in a Pyrex dewar containing 3:1 2-propanol/methanol, cooled to $<-50^{\circ} \mathrm{C}$ with dry ice, and photolysed with $12 \times$ RPR3500 lamps in a Rayonet ${ }^{\circledR}$ photochemical reactor for three hours. Addition of acetic acid $\left(0.2 \mathrm{~mL}, 3.5 \times 10^{-3} \mathrm{~mol}\right)$ to the cold solution caused no change in the characteristic yellow color due to 3e, so was removed from the dewar and allowed to warm to room temperature. The solution turned colorless after ca. 10 minutes at $\sim 20{ }^{\circ} \mathrm{C}$. The solvent and excess HOAc were removed under vacuum to yield a pale yellow oil. ${ }^{1} \mathrm{H}$ NMR of the crude mixture showed two products present, in addition to residual starting material and $\mathrm{Mes}_{2} \mathrm{Ge}(\mathrm{H})\left(\mathrm{SiEt}_{3}\right)$, the product resulting from the trapping of $\mathrm{Mes}_{2} \mathrm{Ge}$ with triethylsilane. The mixture was purified using column chromatography (silica; 1:1 dichloromethane:hexanes). Residual 4 (2 mg) was recovered, followed by 1-hydroxy-1,1,2,2-tetramesityldigermane (7f; $2 \mathrm{mg}){ }^{4}$ formed from traces of water present in the system. The major product was a colorless oil which was identified as 1acetoxy-1,1,2,2-tetramesityldigermane (7e, $8 \mathrm{mg}, 1.2 \times 10^{-5} \mathrm{~mol}, 63 \%$ ) on the basis of the following spectroscopic data: ${ }^{1} \mathrm{H}$ NMR $\left(\mathrm{C}_{6} \mathrm{D}_{6}\right), \delta=1.88(\mathrm{~s}, 3 \mathrm{H}, \mathrm{OAc}), 2.06\left(\mathrm{~s}, 6 \mathrm{H}, p-\mathrm{CH}_{3} \mathrm{~A}\right)$, $2.08\left(\mathrm{~s}, 6 \mathrm{H}, p-\mathrm{CH}_{3} \mathrm{~B}\right), 2.36\left(\mathrm{~s}, 12 \mathrm{H}, o-\mathrm{CH}_{3} \mathrm{~A}\right), 2.40\left(\mathrm{~s}, 12 \mathrm{H}, o-\mathrm{CH}_{3} \mathrm{~B}\right), 6.32(\mathrm{~s}, \mathrm{H}, \mathrm{GeH}), 6.70$ (s, 4H, ArH A), $6.72(\mathrm{~s}, 4 \mathrm{H}, \mathrm{ArH} \mathrm{B}) ;{ }^{13} \mathrm{C}\left(\mathrm{CDCl}_{3}\right): \delta=21.12\left(p-\mathrm{CH}_{3}, \mathrm{~A} \& \mathrm{~B}\right.$ - there are two overlapping signals here that can be resolved in benzene- $\left.d_{6}\right), 23.37\left(\mathrm{CO}^{\mathrm{C}} \mathrm{H}_{3}\right), 23.80\left(\mathrm{o}-\mathrm{CH}_{3} \mathrm{~A}\right)$, 
$24.52\left(\mathrm{o}_{-} \mathrm{CH}_{3} \mathrm{~B}\right), 128.63$ (C3 A), 129.42 (C3 B), 134.51 (C1 A), 136.76 (C1 B), 138.39 (C4 A), 138.92 (C4 B), 142.83 (C2 A), 143.77 (C2 B), $172.01\left(\underline{C O C H}_{3}\right) ; \mathrm{IR}, v\left(\mathrm{~cm}^{-1}\right)=2964(\mathrm{~s}, \mathrm{br})$, 2922 (s, br), 2077 (w), 2034 (w), 1710 (s), 1698 (s), 1602 (m), 1448 (m, br), 1264 (s), 1017 (m), $847(\mathrm{~m}) ; \mathrm{MS}(\mathrm{CI}), \mathrm{m} / \mathrm{z}(\mathrm{I})=682.2 *(9), 621.1 *(90), 563.1 *(17), 503.1 *(11), 431.2 *(17)$ $371.1 *(95), 312.1 *(48), 253.0 *(32), 192.0 *$ (100); HRMS, Calc. for $\mathrm{C}_{38} \mathrm{H}_{48} \mathrm{O}_{2} \mathrm{Ge}_{2}, 682.2061$; found, 682.2087. Several other minor products were also present that were not identified.

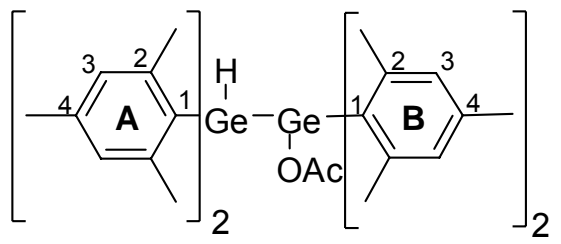

Addition of $\mathrm{Et}_{2} \mathrm{NH}(0.25 \mathrm{~mL}, 0.25 \mathrm{M})$ to a similarly prepared solution of $3 \mathbf{e}$ in $\mathrm{THF}$ at -50 ${ }^{\circ} \mathrm{C}$, followed by standing for 2 days at $4{ }^{\circ} \mathrm{C}$, caused no visual change in the solution. Similar results were obtained when a solution of 3e was treated with $n$-butylamine $(0.13 \mathrm{M})$ under similar conditions.

\section{References}

(1) Leigh, W. J.; Harrington, C. R.; Vargas-Baca, I. J. Am. Chem. Soc. 2004, 126, 16105.

(2) Tsumuraya, T.; Kabe, Y.; Ando, W. J. Organomet. Chem. 1994, 482, 131.

(3) Samuel, M. S.; Jennings, M. C.; Baines, K. M. J. Organomet. Chem. 2001, 636, 130.

(4) Baines, K. M.; Cooke, J. A.; Dixon, C. E.; Liu, H.; Netherton, M. R. Organometallics 1994, $13,631$. 